\title{
Children's magazines: reading resources or food marketing tools?
}

\author{
Sandra C Jones* and Amanda Reid \\ Centre for Health Initiatives, University of Wollongong, Room G04 - Building 41, Wollongong, \\ New South Wales 2522, Australia
}

Submitted 23 April 2009: Accepted 8 July 2009: First published online 26 August 2009

\begin{abstract}
Objective: Magazines targeted at children under 12 years old are growing in popularity; past studies have asserted that food items are rarely exposed, but methodological issues may have covered the true extent of covert promotion. The primary purpose of the present study was to quantify the nature and extent of the promotion of branded food products in Australian children's magazines.

Design: We conducted a content analysis of possible food promotions in seven top-selling Australian children's magazines published in 2005. In addition to regular food advertisements, the number of advertisements for premiums, editorials, puzzles or games, competitions and branded non-food promotions by food companies was recorded. Category frequencies are reported with a detailed description of the promotions present during September 2005.

Results: Only fifty-eight out of the 444 items identified could be classed as regular food advertisements. Several advertisements appeared to be in breach of codes regarding advertising to children and premiums.

Conclusions: The pervasiveness of covert food marketing in the present study was contrary to previous findings and raises questions about the effectiveness of legal restrictions and self-regulation of advertising in protecting children from commercial food messages that may not be regarded as advertising.
\end{abstract}

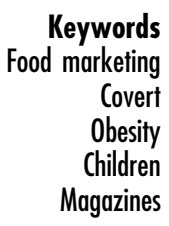

The macro-level factor most commonly implicated as a cause of the rise in obesity is food marketing, which disproportionately promotes the consumption of foods high in fat, sugar and salt ${ }^{(1,2)}$. Several recent studies in Australia and the $\mathrm{UK}^{(3-6)}$ have contributed to public concern over television food advertising, resulting in widespread calls for bans or restrictions on advertising of 'unhealthy' foods during children's viewing times ${ }^{(5,7-9)}$. A major review concluded that research to date does show 'modest direct effects only' of television advertising on food preference, consumption and behaviour ${ }^{(10)}$. However, it has been argued that the effect has been understated in part because the cumulative effect of television advertising combined with other promotional channels is likely to be greater than the effect of television advertising alone, and that research so far has almost exclusively focused on television ${ }^{(11,12)}$.

The opportunity to reach children and teenage youth with print media has expanded over the last decade. Some spin-offs from popular adult titles such as Sports Illustrated for Kids have proved highly successful in the USA ${ }^{(13)}$ and the number of magazines for sale that target younger children is also high and increasing in Australia ${ }^{(14)}$. For example, $K$-Zone is published by Pacific magazines and was launched in 2000. Aimed at children aged 6-13 years, predominantly boys, it claims to provide 'the latest in toys, gaming, anime, sport and entertainment ${ }^{\text {(15) }}$. K-Zone's sister magazine is Total Girl, aimed primarily at 8- to 11-year-old girls. Data from the UK Youth Target Group Index media usage surveys show a change in age distribution and magazine readership over time: for example, in 1994, 50\% of the readership of The Beano (the leading UK boys' title) was aged 7-10 years, while in 2001 this had increased to $75 \%(16)$.

Commentaries on younger children and print materials tend to promote the benefits of print material for improving reading ability; for example, encouraging, for pre-schoolers, the use of magazines that employ familiar television characters $^{(17)}$. Others elaborate on their benefits as valuable classroom learning tools that are visually appealing and written at a wide range of reading levels ${ }^{(18)}$. Importantly, UK findings indicate that parents see children's magazines as trustworthy and educational ${ }^{(19)}$.

Curtis commented that while television advertising aimed at children raises tempers, subtle marketing through children's magazines has gained parental approval ${ }^{(19)}$. The website for Australian Consolidated Press, producers of Disney Adventures, a magazine with a primary target 
audience of boys and girls aged between 9 and 13 years, states that: 'Disney Adventures is a magazine PARENTS trust... READERS have proven to be responsive to advertising campaigns that have been specifically designed to fit in with the editorial content ie: competitions, giveaways. We have seen record numbers of responses for these promotions - this is the essence of our magazine' (bolds, italics and capitals as in original) ${ }^{(20)}$.

Children's magazines carry hidden brand promotions disguised as editorials, comics, games and puzzles ${ }^{(21)}$. Covert marketing strategies deliberately aim to slip 'under the radar', and are highly efficient precisely because they are not clearly distinguishable as marketing ${ }^{(22)}$. The distinction between content and advertising in print media can be subtler than that in television and less obvious to children. The blurring of the lines is reflected in a finding that ten marketing academics could not agree whether selected pages from children's magazines were advertisements or product placements ${ }^{(23)}$.

Acharya et $a l^{(24)}$ provided one of the only two published analyses of children's magazine marketing content that the authors could locate in the literature. According to these authors, who coded 400 pages of the top-selling magazines K-Zone, D-Mag, Disney Adventures and Krash (in October 2005), advertisements comprised 34\% of the pages and product placements made up 29\%. Surprisingly, they asserted that 'food items were rarely exposed (one to three percent) in this issue' (p. 3). However, the present study's authors maintain that the reported figures represent a gross underestimate and that, in the relevant issue of Disney Adventures alone, there were actually more than 10 full pages - plus a large pull-out poster promoting food products, amounting to one-tenth of the magazine. The key distinction made by Acharya et al. ${ }^{(24)}$ is the division of the content into 'advertisement', 'blend of commercial/editorial' and 'non-commercial', and the use of the pages as the unit of analysis is misleading as many pages feature multiple products (in multiple categories).

An analysis of food advertising in UK children's magazines concluded that the majority of food advertisements were for less healthy foods and notably directed readers to the company website ${ }^{(25)}$. In comparison to the huge number of advertisements for other products, that study found relatively few food advertisements. However, covert promotions like product placement, puzzles and games appeared not to be included.

The aims of the current study were to quantify the extent of food promotions in selected issues of Australian children's magazines and provide a detailed description and analysis of the types of promotions that were present. The ultimate goal of this research was to increase awareness and promote informed discussion about a covert marketing tactic that is deliberately used to influence the food choices of children in developed countries, using Australia as a case study.

\section{Method}

A systematic analysis of food advertising and food promotions in Australian children's magazines was conducted for the period January to December 2005. The study used all issues of seven top-selling monthly children's magazines (listed in Table 1), with the exception of three issues of Krash (January, March and April) that could not be located retrospectively. Barbie produced an extra January/February issue; thus there were eighty-two issues in total used in the present analysis. The magazine sample was chosen based on the circulation figures provided by Magazine Publishers of Australia ${ }^{(26)}$. Each issue contained between 84 and 116 pages and was of standard size (height $21 \mathrm{~cm}$ and width $15 \mathrm{~cm}$ ) and format. Free-ofcharge distribution magazines were not included in the present study.

All magazine issues were examined manually by two research assistants, who independently recorded each food and beverage promotion. The unit of analysis was any item mentioning or picturing branded food; thus there could be a number of items per page. If a promotional item involved more than one brand or product, these were coded as separate items. Recorded data included the name and issue date of the magazine, the name of the advertiser and product, the page number, and the categorization of the item into one of seven categories listed in Table 2.

A 'premium' means anything (such as a toy) offered free or at a reduced price and which is conditional upon

Table 1 Description of magazine sample

\begin{tabular}{|c|c|c|c|c|c|}
\hline & Magazine & Circulation* $^{*}$ & Cost (RRP; AU\$) & Target audience & Standard pages \\
\hline 1. & Barbie & 33298 & 4.95 & $5-12$ years, girls & 84 \\
\hline 2. & Disney Adventures & 45273 & $4 \cdot 20$ & $9-13$ years, girls and boys & 100 \\
\hline 3. & D-Mag & 39142 & 4.95 & 9-15 years, girls and boys & 100 \\
\hline 4. & Total Girl & 85431 & $4 \cdot 50$ & $8-11$ years, girls & 116 \\
\hline 5. & K-Zone & 90024 & $4 \cdot 50$ & $6-13$ years, predominantly boys & 116 (up to 140 ) \\
\hline 6. & Mania & 38542 & $5 \cdot 95$ & $7-15$ years, predominantly boys & 100 \\
\hline 7. & Krash & (not in top 100 list) & 4.95 & $11-14$ years, predominantly boys & 100 (up to164) \\
\hline
\end{tabular}

$\mathrm{RRP}$, recommended retail price.

${ }^{*}$ Circulation figures provided by Magazine Publishers of Australia ${ }^{(26)}$; original source Audit Bureau of Circulations Top 100. These figures are for Australia only and represent the audit period July to December 2005. 
Table 2 Total food promotions and September totals in each category across all selected magazine issues

\begin{tabular}{|c|c|c|c|c|c|c|c|c|c|c|c|}
\hline & \multirow[b]{2}{*}{ Coding category } & \multirow[b]{2}{*}{ Total Girl } & \multirow[b]{2}{*}{ Barbie } & \multirow[b]{2}{*}{ Mania } & \multirow{2}{*}{$\begin{array}{c}\text { Disney } \\
\text { Adventures }\end{array}$} & \multirow[b]{2}{*}{ D-Mag } & \multirow[b]{2}{*}{ K-Zone } & \multirow[b]{2}{*}{ Krash } & \multirow{2}{*}{$\begin{array}{c}\text { Sept. } \\
\text { total }(n)\end{array}$} & \multicolumn{2}{|c|}{2005 total $^{*}$} \\
\hline & & & & & & & & & & $n$ & $\%$ \\
\hline A & Regular food ads & 16 & 1 & 0 & 13 & 6 & 18 & 4 & 7 & 58 & $13 \cdot 1$ \\
\hline B & Ads for premiums & 18 & 4 & 0 & 18 & 3 & 19 & 1 & 3 & 63 & $14 \cdot 1$ \\
\hline C & Competitions & 13 & 2 & 12 & 21 & 0 & 23 & 2 & 7 & 73 & $16 \cdot 4$ \\
\hline D & Puzzles or games & 20 & 2 & 0 & 14 & 0 & 27 & 0 & 4 & 63 & $14 \cdot 2$ \\
\hline $\mathrm{E}$ & Promotions not identified as ads & 37 & 7 & 13 & 31 & 5 & 47 & 13 & 13 & 153 & $34 \cdot 5$ \\
\hline $\mathrm{F}$ & Non-food ads by food companies & 5 & 4 & 3 & 3 & 1 & 3 & 0 & 2 & 19 & $4 \cdot 3$ \\
\hline \multirow[t]{2}{*}{$G$} & Is it an ad? & 29 & 6 & 2 & 0 & 1 & 1 & 0 & 7 & 39 & 8.8 \\
\hline & Total & 138 & 26 & 30 & 100 & 16 & 138 & 20 & 4 & 468 & $105 \cdot 4$ \\
\hline
\end{tabular}

${ }^{*}$ Note that twenty-two of the identified items fell into two categories (e.g. a full-page advertisement that included a competition, where the competition was not the sole focus), and one six-page Charlie and the Chocolate Factory attachment fell into three categories (D, C and E); thus the numbers in the table add to more than $100 \%$.

the purchase of a regular (food) product. 'Competitions' could be those that either: (i) you have to buy the food to enter; or (ii) you win the food if you enter. 'Puzzles or games' were included if clearly sponsored or developed by a food company (and included the brand's name, logo or character). The category 'Promotions not identified as ads' refers to editorial pages such as monthly planners. The last category 'Is it an ad?' is a catchall category where a food or brand is clearly visible but may be incidental. The two resulting lists were compared and any discrepancies were resolved by consensus; if agreement could not be reached, the first author acted as the adjudicator.

In order to provide readers with a more complete understanding of the nature of promotions in each category, one month was randomly selected (September) from which to extract examples for a more detailed description of the promotions and the type of products being promoted. Although some advertising variation due to seasonality may plausibly exist, space restrictions preclude a complete account of every promotion.

\section{Results}

A total of 444 different food advertisements/promotions were identified across the magazines for the period (Table 2). One of the most notable findings is that of the 444 items identified, only fifty-eight (13.1\%) could be clearly identified as an advertisement. Within the different magazine titles, Pacific Magazines titles K-Zone and Total Girl clearly contained the highest number of promotions across all categories, with Disney Adventures placing behind these two titles. K-Zone contained a startling number of items that appeared to be 'editorial comments'; and Total Girl stood out as having the most instances where the coders simply could not tell if it was a deliberate placement of the food brand. Krash appeared to contain a relatively low number of promotions; however, it ran a unique regular 'Krash Classifieds' section (eight advertisements to a page) where products were 'advertised for suitable consumers' (like a mock employment section).
The following section describes some of the forty-three branded promotions appearing in September 2005. Category totals for that month are shown in Table 2 and represent those for all magazines combined; however, the examples below are restricted to K-Zone, Total Girl and Disney Adventures - the main magazines to carry food promotions.

\section{Promotions during September 2005}

\section{Regular advertisements}

In Total Girl, only one straightforward advertisement was identified: this was for Allen's Mixers (pp. 56-57), a type of chewy lolly (candy) that you can 'mix and match'. This also appeared in $K$-Zone (pp. 52-53), with a heading 'invent new flavours' and a picture of the packet. In addition, $K$-Zone included two linked ads (p. 31 and p. 33) for Green's baking products (muffins and cookies). The first read 'Awesome cooking... and exciting reading! - Find an exclusive Paul Jennings "Uncooked" mini-book inside selected Green's packs - Collect all 5!' K-Zone also included a full-page advertisement for Trolli candy (p. 112). Disney Adventures had no branded food advertisements in September (although a substantial number across the remainder of the year), but did have the only placement of the 'Jo Lively' advertisement (p. 33) - the 'Initiative of the Marketing, Advertising, and Media Associations' which features an animated figure balancing on a stack of food (a steak, an apple and a celery stick) and holding a carton of milk. It was accompanied by the text 'Balance what you eat, get up on your feet', and the logo and tag line 'eat well, play well, live well'.

\section{Premiums}

In both Total Girl and K-Zone, a double-page advertisement on the inside front cover (pp. 2-3) read 'Get your favorite gaming heroes at McDonald's - Spyro \& Crash Electronic Games - This heroic little dragon or this cheeky, out-of-control daredevil are featured in your very own hand-held electronic game, with multiple levels and cool graphics' and featured a large cartoon graphic of 
the two characters and pictures of the eight games. Approximately two-thirds of the way down the page it read ' 8 exclusive games to collect. Find one inside your Happy Meal from 26th August 2005'. The only other references to the food products were a small 'Happy Meal logo' in the top centre and - in very small print - 'One toy per Happy Meal'. There was no picture of the food, and no description of the meal content.

K-Zone included a full-page advertisement promoting the YoGo Alley website (p. 100) - YoGo is a flavoured dairy-based dessert. The fact that this is actually a premium was only evident when examining the smaller print in the bottom left-hand corner, which read 'Purchase your specially marked YoGo Alley2 Promotional 12 pack in supermarkets now, collect the unique code and log on!'

\section{Competitions}

A two-page advertisement for a competition run by Nestlé in conjunction with the movie Charlie and the Chocolate Factory appeared in Total Girl (pp. 34-35), Disney Adventures (pp. 2-3) and K-Zone (pp. 46-47). The headline read 'Chocolate Factory Frenzy - Finders of 5 Golden Tickets to go inside Chocolate Factory'. Entry into the competition required the reader to purchase a Nestlé Wonka chocolate bar, find a golden ticket inside, and check the number on a dedicated website. The major prize was one of five trips for two adults and two children to the Nestlé UK chocolate factory. Disney Adventures included a full-page advertisement for a competition to 'WIN your height in chocolate' on the last page of a 12-page 'pull-out and keep' Charlie and the Chocolate Factory movie feature. K-Zone included a full-page advertisement for a competition to 'WIN one year's supply of Wonka chocolate' (p. 20).

A two-page advertisement for a competition run by Kellogg's LCMs (a cereal and milk bar that comes in a range of five flavours) appeared in Total Girl (pp. 44-45) and $K$-Zone (pp. 24-25). The headline was 'What Could LCMs Stand For?' and the advertisement read 'Win an iPod mini! - To win your very own iPod mini, tell us what you think the letters LCMs could stand for and draw a picture of your idea'.

\section{Puzzles or games}

Four puzzles or games were identified; all featured the colours, logos and characters from the product packaging and advertising, and in most cases the puzzle questions and solutions were associated with the product. Total Girl included a full-page 'Spot the Difference' puzzle (p. 27) featuring 'Coco', a cartoon monkey who is the mascot for Coco Pops (a chocolate-flavoured, rice-based breakfast cereal). The text read, 'While Coco's busy making a splash, why not take the plunge and see if you can spot the ten differences in his underwater world...' There was a small picture of Coco holding a box of Coco Pops in the top right-hand corner of the page, but no other reference to the food product. The answers were provided on a half-page later in the magazine (p. 88), again with a picture of Coco holding a box of Coco Pops.

K-Zone included a full-page 'Coco's Word Search' puzzle (p. 63), featuring Coco and a full-page 'spot the difference' puzzle entitled 'Food Has Never Been This Much Fun' (p. 86) involving the product Dairy Whip (whipped cream). K-Zone also included an eight-page 'sealed section' entitled 'Hypno-Zone'. The lower section of the cover page included a photo of three packs of Swirls (a bread product), two slices of Swirls toast popping from a toaster (under the heading 'Hypnotically Delicious') and the text 'Hypno-zone is brought to you by the new cool Tip Top Swirls bread! Fruit \& Spice, Apple \& Cinnamon, Sultana \& Choc! Get some into your toaster right now!' The Hypno-zone included: two pages on hypnotism; a page of 'swirly stats' (e.g. 'Number of sultanas in a slice: 24') and tips for alternative uses for Swirls (e.g. 'Stick it in your sister's CD rack...'); a page on top ways to eat Swirls; a one-page crossword puzzle (including clues such as 'Australia's fave bread!'); a onepage hypnotism quiz (including the question 'What are the three hypnotic flavours of Tip Top Swirls bread?'); and a one-page maze with the instructions 'Which of these super-hungry 3 are going to get the hypnotically delicious swirls in their tummy and who's going to have to wait'.

\section{Promotions not identified as ads}

Six of the seven magazines (the exception being D-Mag) included one or more 'editorial columns' in which food products were explicitly promoted. The monthly planner page of Total Girl included: 'Go Green - FREE Paul Jennings UNCOOKED! mini book inside GREENS ... products!' (p. 9). The monthly 'What a Girl Wants' column of September's Total Girl (a column in which each of the editorial staff reports on one (fab find we're loving...') included: (from 'Andree') a photo of two hand-held games and a Happy Meal logo and the quote 'My favourite gaming heroes are at McDonald's! There are eight exclusive Crash or Spyro hand-held electronic games to collect. Find one inside your Happy Meal from August 26' (p. 10). The same column also included: (from 'Olena') a photograph of Nestlé Wonka chocolate bars and the quote 'Phew! I've been busy munching on Nestlé WONKA Whipple Scrumptious Caramel Delight, determined to find a Golden Ticket! It's the best excuse to eat chocolate yet!' (p. 11).

The editorial page of Disney Adventures (p. 4) includes a regular section entitled 'Hot or Not' which updates readers on what is currently (un)cool. The 'Hot' list referred to Wonka candy and chocolate products: 'Wonka Hat with Nerds. Mmmm... Chocolate!' The regular 'Calendar' column in K-Zone recommended that on September 13 readers 'Check out Swirls - in supermarkets now!' and on September 25 that readers 'Have fun with Yummy LCMs at recess'. The regular 'Cough Up Ya Cash' column in $K$-Zone (pp. 82-83) advised readers to 'Wait till 
your piggy bank is full to the brim, then smash it open and go on a spending frenzy grabbing this lot!' Featured products were Tip Top Swirls bread and McDonald's Happy Meals.

\section{Is it an ad?}

Ronald McDonald's Safety Tips in Disney Adventures (p. 17) provided pool safety tips for readers. The feature included the McDonald's logo and a photo of Ronald McDonald, but no mention of food. Total Girl featured recipe ideas in the form of Pizza Faces (pp. 60-61) - this incorporated a picture of Leggo's tomato paste and Golden Circle pineapple slices. The 'Street Talk' column in Disney Adventures (p. 14) asked kids to describe the ultimate chocolate bar - it included two photos of (unwrapped) chocolate bars, Cadbury's Caramello Koala and Nestlé's Peppermint Crisp. The 'Weird Yet True' column in Disney Adventures (pp. 27-28) focused on chocolate facts and included a story about a woman who bought 10656 Mars bars and another about the world's largest Cadbury's Dairy Milk chocolate bar.

\section{Discussion}

Children's magazines are growing in popularity and are often considered to be educational reading resources. In the current study of food promotions in seven of these magazines, the use of commercial material regarding food was pervasive and much of this material was covert or embedded, integrating the advertising into the entertainment in order to engage the child with the product. Further, given that there were seventy-three items identified as competitions, it is also possible that readers are exposed to further marketing after personal details are collected as part of filling out competition forms.

The number of food promotions identified in the current study is in stark contrast with assertions in previous research $^{(24,25)}$ regarding the rarity of food promotions in children's magazines, although the covert techniques found were similar to those detailed by Cowburn and Boxer ${ }^{(25)}$ regarding Internet marketing to children. The present study included all of the four titles analysed by Acharya $e t$ al. ${ }^{(24)}$ but used a much larger sample of issues (eighty-two $v$. four). In line with Acharya and Mizerski's report that it was difficult to judge whether children's magazine material was of a commercial nature ${ }^{(23)}$, the research reported here found that over one-third of the items identified appeared to be independent editorial comments rather than advertisements (e.g. the 'calendar' or 'what's hot' columns). While it was beyond the scope of the project to ascertain whether or not these comments were (directly or indirectly) paid placements, they often appeared when regular advertisements for a particular product were also present in the same magazine issue. Magazine readers were repeatedly provided with brand cues, inducing more favourable attitudes towards the brand via increased familiarity. 'Mere exposure' theory proposes that mere exposure (i.e. limited processing) is enough for this process to occur ${ }^{(27,28)}$.

K-Zone and its sister magazine Total Girl stood out as being the most commercially oriented titles in the present study. They have the highest circulation figures and the most pages per issue - allowing for more promotional space. In assessing the impact of these magazines, it is important to note that actual readership may be far higher than the number of issues sold. For example, the Pacific Magazines website indicates that circulation and readership figures for K-Zone in 2006 were 70234 and 294000 , respectively ${ }^{(15)}$.

Currently in Australia, television advertising to children is regulated through the Australian Communications and Media Authority, which includes content quotas on commercial free-to-air broadcasters relating to quality children's programming and restrictions on the advertising that can be shown during this programming. However, non-television advertising (e.g. print) is selfregulated by the industry, with two codes of primary relevance to the present paper: (i) the AANA (Australian Association of National Advertisers) Code for Advertising and Marketing Communications to Children (revised in April 2008), which covers issues such as factual presentation, safety, parental authority, qualifying statements, competitions and premiums ${ }^{(29)}$; and (ii) the AANA Food and Beverages Advertising and Marketing Communications Code ${ }^{(30)}$, which covers similar issues as well as not encouraging excessive consumption and not undermining parents' role in guiding diet and lifestyle choices. The AANA Code for Advertising and Marketing Communications to Children provides that advertisements to children which include or refer to a premium should not create a false or misleading impression in the minds of children about the nature or content of the advertised product or about whether the product advertised is the premium rather than the product (clause $2 \cdot 8$ ). The advertisements featuring the Spyro \& Crash Electronic Games placed by McDonalds into K-Zone and Total Girl in September are clearly in breach of codes regarding advertising to children and premiums. There was no picture of the food, and no description of the Happy Meal content. This finding is perhaps not surprising given that a recent study of $645 \mathrm{~h}$ of free-to-air television found 194 apparent breaches of Children's Television Standards, with many of these breaches relating to the focus on premiums $^{(4)}$.

To further complicate the food messages that children are receiving, Disney Adventures featured the 'Eat well, play well' campaign, purportedly developed to educate children aged 6-12 years on energy intake and exercise output (see www.jolively.com). The campaign had been conducted across most media channels using nearly \$AU 10 million in donated space by April 2006. While 
communicating the message to eat a balanced diet is significant and admirable, this campaign itself is still clearly out of balance with the barrage of branded magazine promotions identified in this study. When the Sun Herald newspaper interviewed Robert Koltai, AANA Vice-Chairman, about this campaign in 2003, it reported, 'he conceded it was designed to take the heat off the advertising industry for its role in promoting fast food to children, $^{,(31)}$.

While the present study was conducted in Australia, using Australian magazines (which target an Englishspeaking population, with none of the magazines targeting specific cultural or language groups), the implications of the findings are potentially relevant to the USA and other developed countries; although additional research would need to be conducted to assess the level and nature of content in magazines targeted at specific ethnic groups. It is important to note that the current study used a sample of magazines that are sold for approximately \$AU 5.00 per issue (roughly \$US 4.00); thus future studies could compare the level of advertising in no-cost magazines which would likely have a different distribution of readers. Future research could include an analysis of the 'healthiness' of the branded foods and analysis of information on websites promoted in the advertisements. Coding categories were developed specifically for the present analysis; further studies that validate these and determine inter-rater reliability would be useful.

The current study used magazine issues from 2005 there may have been changes in the number and style of food promotions included since this time (particularly since the introduction of the new AANA Code in 2008), and ongoing monitoring is needed. Importantly, these publications also contained an overwhelming number of promotions - both covert and otherwise - for products other than food, such as toys and computer games; and in female-targeted publications, for clothes and cosmetics.*

\section{Implications for research and practice}

Concerns regarding childhood obesity and the effects of television food advertising suggest that food marketing in children's magazines demands more attention. The findings of the present study need to be communicated to the parents and guardians who buy children's magazines, so that they can make an informed decision about these purchases, and to policy makers who are looking to enhance children's welfare. It has been suggested that legal restrictions and self-regulation of advertising are the answer to criticism of child-targeted advertising ${ }^{(32)}$; but this pervasiveness of covert marketing raises questions

* While we did not count all of these promotions, as the focus of the study was food promotions, there were more than 1000 explicit advertisements for non-food products across the 12 months of the seven magazines. about the effectiveness of such systems in protecting children from commercial food messages that may not be perceived as 'advertising'. Researchers need to focus on the conditions under and the ages at which children are able to identify covert magazine marketing, and their reactions to its presence.

It is hoped that the research presented here will help promote informed discussion about the covert tactics used by marketers to integrate commercial food products with magazine entertainment and play activities.

\section{Acknowledgements}

This research received no specific grant from any funding agency in the public, commercial or not-for-profit sectors. The authors have no conflicts of interest. S.C.J. developed the study protocol, oversaw data collection, conducted the analysis and co-wrote the manuscript. A.R. acted as one of the coders, assisted in interpretation of the data and co-wrote the manuscript. The authors thank Belinda Fabrianesi for assistance with data collection and coding.

\section{References}

1. McGinnis M, Gootman J \& Kraak V; Committee on Food Marketing and the Diets of Children and Youth (2006) Food Marketing to Children and Youth: Threat or Opportunity? Washington, DC: Institute of Medicine of the National Academies.

2. Powell LM, Szczypka G, Chaloupa FJ \& Braunschweig CL (2007) Nutritional content of television food advertisements seen by children and adolescents in the United States. Pediatrics 120, 576-583.

3. Australian Divisions of General Practice (2003) What Are We Feeding Our Children? A Junk Food Advertising Audit. Canberra: Australian Divisions of General Practice.

4. Chapman K, Nicholas P \& Supramaniam R (2006) How much food advertising is there on Australian television? Health Promot Int 21, 172-180.

5. Kelly B, Smith B, King L, Flood V \& Bauman A (2007) Television food advertising to children: the extent and nature of exposure. Public Health Nutr 10, 1234-1240.

6. Jenkin G, Wilson N \& Hermanson N (2009) Identifying 'unhealthy' food advertising on television: a case study applying the UK Nutrient Profile model. Public Health Nutr 12, 614-623.

7. Pritchard C (2003) Food marketers feel the heat Down Under. Market Mag issue 10, 7.

8. Esplin H (2002) NSW: Calls for food ads on TV to be banned. Australian Associated Press Newsfeed (Sydney), 11 September.

9. Coalition on Food Advertising to Children (2008) Official website. http://www.chdf.org.au/ (accessed February 2008).

10. Ofcom (UK Office of Communications) (2004) Childhood Obesity - Food Advertising in Context. Children's food choices, parents' understanding and influence, and the role of food promotion. http://www.ofcom.org.uk/research/tv/ reports/food_ads/report.pdf (accessed February 2008).

11. Hastings G, Stead M, McDermott L, Forsyth A, MacKintosh AM, Rayner M, Godfrey C, Caraher M \& Angus K (2003) Review of Research on the Effects of Food Promotion to Children. Glasgow: University of Strathclyde. 
12. Swinburn B, Sacks G, Lobstein T, Rigby N, Baur LA, Brownell KD, Gill T, Seidell J \& Kumanyika S; International Obesity Taskforce Working Group on Marketing to Children (2008) The 'Sydney Principles' for reducing the commercial promotion of foods and beverages to children. Public Health Nutr 11, 881-886.

13. Kaiser Family Foundation (2004) Key Facts: Tweens, Teens and Magazines. Menlo Park, CA: Kaiser Family Foundation.

14. Anon. (2005) ACP, Pacific moot new youth launches. $B E T$ Weekly, 26 August.

15. Pacific Magazines (2008) Official website. http://www. pacificmagazines.com.au/ (accessed February 2008).

16. McMahon L (2002) Understanding the dynamics of youth readership. Int J Advert Market Child 3, 53-61.

17. Harding J (2004) Learning from pre-school magazines. Young Consumers 6, 30-37.

18. Morrow LM \& Lesnick J (2001) Examining the educational value of children's magazines. California Reader $\mathbf{3 4}$, issue 2, 2-13.

19. Curtis J (2004) Small targets. Marketing 19 May, 38-40.

20. Australian Consolidated Press (2008) Official website. http://www.acp.com.au/Publication.aspx?id=6feacd74-796f4e6f-92b4-fddb51e05659\&mag=Disney+Adventures/ (accessed February 2008).

21. Kraak V \& Pelletier DL (1998) How marketers reach young consumers: implications for nutrition education and health promotion campaigns. Fam Econ Nutr Rev 11, 31-41.

22. Danish Consumer Ombudsman Guidelines (2005) Covert marketing activities: identifying commercial communication. http://www.forbrug.dk/english/dco/dcoguides/ guidelines-and-guidances/covertmarketing/ (accessed February 2008).

23. Acharya DS \& Mizerski R (2005) Expert opinion on the content and intention of material from a magazine targeted to 7 to 10 year old beginning readers. Australian and New Zealand Marketing Academy Conference, pp. 1-7. http:// smib.vuw.ac.nz:8081/www/anzmac2005/cd-site/authors1. html/ (accessed February 2008).

24. Acharya DS, Mizerski R \& Rexha D (2006) Advertising and product placements in top Australian children's magazines. Australian and New Zealand Marketing Academy Conference, pp. 1-7. http://smib.vuw.ac.nz:8081/WWw/ ANZMAC2006/authors.html/ (accessed February 2008).

25. Cowburn G \& Boxer A (2007) Magazines for children and young people and the links to Internet food marketing: a review of the extent and type of food advertising. Public Health Nutr 10, 1024-1031.

26. Magazine Publishers of Australia (2005) 2005 Top 100 Magazine Circulation (Australia Only). http://www. magazines.org.au/ (accessed April 2006).

27. Janiszewski C (1993) Preattentive mere exposure effects. $J$ Consum Res 20, 376-392.

28. Auty S \& Lewis C (2004) Exploring children's choice: the reminder effect of product placement. Psychol Market 21, 699-716.

29. Australian Association of National Advertisers (2008) AANA Code for Advertising and Marketing Communications to Children. http://www.aana.com.au/documents/Code Children.pdf (accessed June 2009).

30. Australian Association of National Advertisers (2006) AANA Food and Beverages Advertising and Marketing Communications Code. http://www.aana.com.au/documents/ CodeFoodBeverage.pdf (accessed June 2009).

31. Leggatt J (2003) Ad industry urges kids to eat right. Sun Herald Sydney, 9 March.

32. Petterson A \& Fjellstrom C (2006) Responsible marketing to children and their families. Young Consumers 7, 13-18. 